\title{
Dilthey and Human Science: Autobiography, Hermeneutics and Pedagogy
}

Norm Friesen, Boise State University, Idaho

Email: normfriesen@boisestate.edu

\begin{abstract}
Using Maya Angelou's I Know Why the Caged Bird Sings as an example, this paper introduces Wilhlem Dilthey's (1833-1911) hermeneutics and pedagogical theory. Dilthey saw biographies (and autobiographies like Angelou's) as nothing less than "the highest and most instructive form of the understanding of life." This, then, serves as the starting point for his hermeneutics or theory of understanding, which distinguishes humanistic understanding from scientific explanation, and sees any one moment or word as having meaning only in relation to a whole - the whole of a sentence or text, or the whole of one's life. It is also the starting point of his pedagogy, whose ultimate "duty" is "to develop the child as a person who carries their own purpose within themselves." In introducing Dilthey's hermeneutic pedagogy, this paper draws principally from his The Formation of the Historical World in the Human Sciences (1927/2002), a text that has been long neglected in hermeneutic and phenomenological studies of education.
\end{abstract}

\section{Introduction}

As I'd watched Momma put ruffles on the hem and cute little tucks around the waist, I knew that once I put it on I'd look like a movie star... . I was going to look like one of the sweet little white girls who were everybody's dream of what was right with the world. ${ }^{1}$

Maya Angelou's famous autobiography, I Know Why the Caged Bird Sings, opens with a young Maya dreaming of looking like a movie star. The dress she watches her mother sew will transform her, she imagines, into another person, into a "sweet little white girl" of people's dreams. These childhood fantasies, of course, do not come true. Instead, despite profound hardships while growing up, young Maya goes on to study dance and drama at a school in San Francisco and becomes the city's first black female streetcar conductor.

Maya's story is a compelling one. But the purpose of this review article is to take a step back and focus not so much on the story itself, but about how we understand it.

\footnotetext{
${ }^{1}$ Angelou, M. (1969). I know why the caged bird sings. New York: Random House, pp. 3-4.
} 
For example, when we read a selection from its powerful opening, we are not confronted by discrete facts or information about Maya. We don't know her age, where she lives, or what year it is - nor do we really need to. In reading Angelou's famous autobiography, we are not simply absorbing facts and data; instead, we are entering a story, into the experiences and memories of someone who is simultaneously author and protagonist. More than this, we are entering into a history, specifically a personal history of the author. And this history is important, even when Maya at some points appears to leave it behind. This is because Maya's early dreams and desires still remain a part of who she $i s$ - even after Maya outgrows them. The past matters here, in short, because it is part of a greater whole that is Maya's life.

Also, we understand her story - even if only superficially - despite the fact that we may come from very different backgrounds. Our own memories and experiences may differ a great deal from Maya's. Regardless, our memories and experiences work as resources that help us appreciate Angelou's autobiography, and they provide us with some understanding for what is happening and why. They allow us to participate not only intellectually, but also with our own feelings, wishes and desires. For example, when we read of Maya's dream of looking like a sweet little white girl, we may already worry that such a dream reflects a history of racial injustice, and that it will be cruelly crushed. We might also imagine that young Maya will likely have to deal with many similar disappointments as she grows older.

But what does all of this have to do with human science and pedagogy? What's the connection of Angelou's life to Wilhelm Dilthey, and his famous The Formation of the Historical World in the Human Sciences (1910/2002)?

The short answer is that Dilthey wanted to understand life. He didn't want to explain it in causal, psychological, or sociological terms, but to understand what people experience in individual moments of the day, and what we undergo in the course of a lifetime. In his The Formation of the Historical World, Dilthey makes it clear that autobiography-writings like Angelou's - represents nothing less than "the highest and most instructive form of the understanding of life" (Dilthey, 2002, p. 221). ${ }^{2}$ Autobiography for him was "the most direct expression of reflection about life" (p. 219). An autobiography like, I Know Why the Caged Bird Sings does not simply tell us the story of a person, of Maya Angelou. It shows us what it is like to live a life, to be alive, and also to be an individual in the world both in a specific time and place and in more general terms as well. In fact, Dilthey devoted a large part of his life to his own history project: an extensive but unfinished biography of a thinker and personality who probably was the greatest single influence on his own thinking-Friedrich Daniel Ernst Schleiermacher. Dilthey's The Life of Schleiermacher spans two volumes and, as one reader said, aims at nothing less than "the inner life of Schleiermacher as an individual, the unity of this individual in his groundedness in his own self, and the entirety of his life processes and relationships" (as quoted in Son, 1997, p. 79). ${ }^{3}$

\footnotetext{
${ }^{2}$ All subsequent references provided with an author or date are references to Dilthey's The Formation of the Historical World in the Human Sciences.

${ }^{3}$ All non-English sources quoted are translated by the author.
} 
But what is important for Dilthey and also for us here is not simply what happens in a life like Schleiermacher's or Maya Angelou's — as important or interesting as their lives may be. Instead, what is important is how we reflect on this life or on our own lives, how we comprehend and interpret them, and how such interpretation is expressed: "The comprehension and interpretation of one's own life," Dilthey says, "goes through a long series of stages. Its most complete explication is autobiography" (p. 225). Dilthey, in other words, saw autobiography as exemplifying the type of interpretation, reflection, and knowledge - in short, the type of science - that is human science.

Before a life is expressed through an award-winning autobiography like Angelou's, as Dilthey says, it first goes though many stages. Memories like a young Maya watching her mother at the sewing machine aren't simply collected or accumulated haphazardly in an artful biography. They are not a random selection from a dataset. The many moments and memories in Angelou's autobiography instead gain their power and meaning not in isolation, but through their intimate interconnection. They are interconnected not only with each other, but also with the greater whole that is ultimately Angelou's life. And from there, in Angelou's case, they are further connected to the broader history of the south, of Black America, and of the United States as a whole. Dilthey says: "The individual moment has meaning through its connection with a whole, through the relation of past and future [even through the relation of] individual existence and [all of] humanity" (p. 253). The scene at the sewing machine, for example, has meaning because it is interconnected with other scenes and events - not just with Maya's dream of being a sweet little white girl, but also in a sense with her eventual growth to become an accomplished young woman. Such moments are meaningful and powerful also because they are part of and closely connected to the whole of her life. Dilthey puts this more abstractly: "The category of meaning designates the relationship of parts of life to the whole as rooted in the nature of life" (p. 253). And the ultimate meaning of such a life, Dilthey adds, "is unique and cannot be fathomed by conceptual cognition" (p. 221).

In going beyond "conceptual cognition," Dilthey is emphasizing that meaning is not just an intellectual matter, but one that instead involves "the concurrence of all the powers of the psyche" (Dilthey, as quoted by Makkreel, 1977, p. 6). It is a vital combination of "willing, feeling and thinking," as Dilthey liked to say. As suggested above, as we witness the emergence of a dignified young person from Angelou's difficult origins, we are engaging also with our own feelings, aspirations, and disappointments. Our feeling, willing, and thinking serve as resources that allow us to participate, virtually and to different degrees, in Maya's history, her suffering and accomplishments. In this sense, understanding can be described as a process that comes from "within"- from our own memories, feelings, and experiences, connecting with Maya's own internal life, her aspirations, achievements, and disappointments.

Comparing this personal-historical way of understanding with the natural sciences, Dilthey writes: "In the historical world there is no natural science causality...for a cause, in this sense, implies that it produces effects that are necessitated in accordance with laws." Personal or collective histories, he insists, are different: "history only knows of relationships of agency and 
Friesen

suffering, action and reaction" (p. 219; emphasis in original). An account only of causes and effects simply would not be a story. It is precisely "relationships of agency and suffering, action and reaction" that define the narrative arc of Maya's history just as they do our own lives. For example, we "suffer" particularly in the sense that things happen to us: We meet someone significant, we have an accident or fall ill. At the same time, we also act and exercise agency: we earn a scholarship or degree, or we decide to get married or divorced. Of course, for her part, Maya manages to rise above the suffering that others inflict on her to act for herself, to exercise her own will, judgment, and agency.

As already suggested, Dilthey sees a personal history like Maya's as part of history in the broadest sense. "The historical world is always there, and the individual does not merely contemplate it from without; instead [he or she] is intertwined with it" (p. 297). In fact, Dilthey sees the two - personal "history" and "capital-H history" — as closely intertwined: In "the lifecourse of a historical (personality), the individual receives influences from the historical world, is molded by them" (p. 266; emphasis added). This same person," Dilthey adds, "also exerts his or her influence on the historical world." As a famous author and activist, Maya Angelou certainly left her mark "on the historical world." She worked with Martin Luther King and Malcolm X in the early 1960s, and famously read her poem "On the Pulse of Morning" at President Bill Clinton's 1993 inauguration. She also received many international honors upon her death in 2014.

Although her personal life story has now ended, Angelou's legacy as an artist and a public figure live on. The task of understanding the scope and significance of her life as well as of her creations continues. But this is ultimately true, albeit on a different scale, of any person and their life, as Dilthey explains: "The mystery of the person lures us for its own sake into ever new and deeper attempts at understanding. In such understanding, the realm of individuals, encompassing human beings and their creations, opens up" (p. 233).

Understanding another person, another human being, is, as Dilthey says, the "most distinctive contribution of the human sciences" (p. 233). Our attempts to understand someonetheir willing, feeling, and thinking through our own, never really end: there are always "new and ever deeper" interpretations and understandings to be reached. In addition, Dilthey emphasizes that for all of their great triumphs and advances, the natural sciences ultimately do not help our ability to deal with the ultimate interpretation, the ultimate meaning and value of a person's life and accomplishments:

Our present age does not confront...the value of our being, the final value of all our actions any more knowledgeably than a Greek in the period of the ionic or of the Italian colonies, or than an Arab in the time of Ibn Roshd [a.k.a. Averroes; a great Arab thinker of the $12^{\text {th }}$ century]. Today, surrounded as we are from the rapid progress of science, we confront these questions with even greater helplessness than in any previous time. (1977, p. 193) 
Even though we can do all sorts of things in our own lives thanks to technology and the natural sciences - from rapid air travel to gender reassignment surgery - we still struggle to come to terms with the life (or death) of a friend or loved one, and its meaning for us and for others. And the more we remove ourselves from the comforting narratives and certainties of religion, the more our "helplessness" seems to grow. In the human sciences, this ongoing task of grappling, of seeking to understand, is known as hermeneutics. Defined as the art and science of interpretation, hermeneutics is seen by Dilthey as the central method of the human sciences. As Dilthey puts it, "the method pervading the human sciences is that of understanding and interpretation" (p. 226). The fullness of our understanding of another life, Dilthey says, "emerges from present and remembered lived experiences" (p. 326). And it is "this insight," he adds, that "in the human sciences lies at the basis of all reflection on these sciences" (p. 326). The way that we have just begun to understand the smallest part of Maya Angelou's life, in other words, shows us how we understand anything — any person, act, word, creation, life, or death.

\section{Hermeneutics}

Because we've already understood (at least a little about) Maya's life, we also understand something about hermeneutics. Actually, we've already outlined the three main characteristics of hermeneutics in discussing Angelou's autobiography. These are:

1) We come to know and understand things like our own lives and experiences - and those of others-by beginning with what we already know and have experienced. In the human world, what we already know and feel serves as a resource for all understanding.

2) This process of understanding continues by giving individual moments, memories, and experiences meaning by weaving them together with each other and with a greater whole-even connecting them with "capital-H history."

3) This "weaving" and interpretation involves all of our "willing, feeling, and thinking" in a process that ends only when we die.

In the next sections of this article, I explain these three aspects of hermeneutics in detail.

\section{You begin with what you've already experienced.}

As we know, in the case of Angelou's autobiography, "what we already experienced" includes a great deal, for example: What we already may know about her book and her life, what we know about the American South, about San Francisco, about sewing and dressmaking, as well as about "black life in America." (At the same time, there are certainly many things that we don't know in relation to her autobiography, and there are things we may think we know but that may be corrected through later experience. In hermeneutics, these mistaken understandings are called "prejudices" and are discussed further below.) According to hermeneutics, we are able to understand because we already have at least some things in common: Like Maya, we've all "grown up," we know what it's like to belong — and also to be excluded (even if in very different 
types of contexts). Even more fundamentally, we're all participants in the many ways of thinking and feeling encoded into the English language. This important point means much more than that we simply use the same words to label the same things in the world. It means that we use the same oppositions - opposites like black vs. white, rich vs. poor, male vs. female, South vs. North - to structure our thinking, for better or for worse. And this is only the beginning. Names like "Arkansas" versus "San Francisco," "momma" or "movie star" bring with them a wide range of connotations, and possible and real experiences. Although the precise associations and experiences these names might bring naturally vary from one person to the next, they all form part of a pool of knowledge and experience. Dilthey puts it this way:

Every word or sentence, every gesture or polite formula, every work of art or political deed is intelligible because a commonality connects those expressing themselves in them and those trying to understand them. The individual always experiences, thinks, and acts in a sphere of commonality, and only in such a sphere does he understand. ... Because of the variety of life-manifestations to which we are exposed, we are constantly challenged to new understanding. (pp. 168-169; emphasis added)

Even though we have much in common, Dilthey emphasizes, we are always challenged in our understanding - for example, about Arkansas, about Black experience, about American history. Dilthey would acknowledge that some if not many of the understandings we bring to a reading of texts may be uninformed or even misinformed. Hans Georg Gadamer, a $20^{\text {th }}$ century hermeneutician who in many ways followed in Dilthey's footsteps, referred to these as preunderstandings and prejudices. However, Gadamer (2004) was not speaking so much of deeply ingrained biases and ideologies that seem so impervious to change. Instead, he had in mind knowledge (and ignorance) that we are both willing and able to change - what we might call "pre-judgments" rather than prejudices.

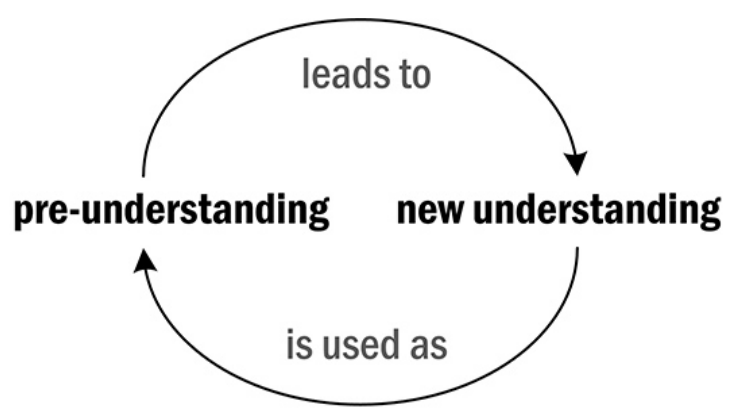

Figure 1: The hermeneutic circle in a world of shared meaning traces a movement from pre-understanding, through new experience, to new understanding. Later, as still further experience is encountered, this new understanding serves as pre-understanding for still further interpretation.
Gadamer, like Dilthey, believed that although we begin with what we know and have experienced, these things are constantly shown to be inadequate - and they can also need to be adjusted, corrected, and augmented (Figure 1).

Encountering something new or different (which happens all the time, in ways larger or small) means that our existing "prejudgments" or "pre-understandings" change and develop. New or different understandings and meanings arise for us. And as we continue in the ongoing activity of interpretation, these new understandings 
eventually become "pre-understandings" of their own. And we then use these new preunderstandings to understand still further experience. Understanding, in this sense, takes the form of a circle. Our preunderstanding - our previous willing, feeling, thinking — helps us understand something new. And this new understanding then is what helps us interpret still further experience and meaning. This circle is known as the hermeneutic circle and-as shown in figure 1 and in further diagrams below-it appears in a number of forms.

We're always learning, as the expression goes, and for the human sciences, this means that we are always making use of what we've already experienced as we engage with new experiences, possibilities, and realities. And because our "pre-understandings" keep on changing, this means that we can always return to a given experience, to a particular possession, memory, or story, and gain something new from it. We can re-read a favorite book, or replay a familiar movie, and find new things to learn and enjoy. This is because we're always bringing new and more informed pre-understandings to it — new knowledge, life experiences, and awareness that sheds new light on its characters and the narrative. Meanwhile this book or movie actually just presents the same words on the page, and the same images on the screen. But it is we who have changed.

\section{You connect parts with a whole.}

The hermeneutic circle, however, not only connects previous understandings with new ones; as already suggested, it also connects parts - an individual moment, memory, or experience - with a whole. A single experience, a conversation, a decision or action, of course, does not contain its full meaning within itself; it gains meaning by its connection with a larger context (Figure 2). Winning a scholarship or deciding to get married may obviously be momentous events, but their ultimate meaning comes from the greater whole of one's own and other's lives — not from the isolated individual moment itself. "The individual moment has meaning," as Dilthey said earlier, "through its connection with the whole, through the relation of past and future" (p. 253). We already saw how some of the opening moments in Maya Angelou's story gain further meaning by being connected to the greater whole that her life was eventually to become. In understanding, in the hermeneutic circle, we not only move from preunderstandings to new understandings, we also move from individual detail, memory, or part to a greater whole_-and back again.

This movement from part to whole is the case in our own lives or in an autobiography just as much as it is in everyday communication. Dilthey points out how part and whole also work in individual sentences to produce meaning. Consider the simple phrase: "Hanging softly

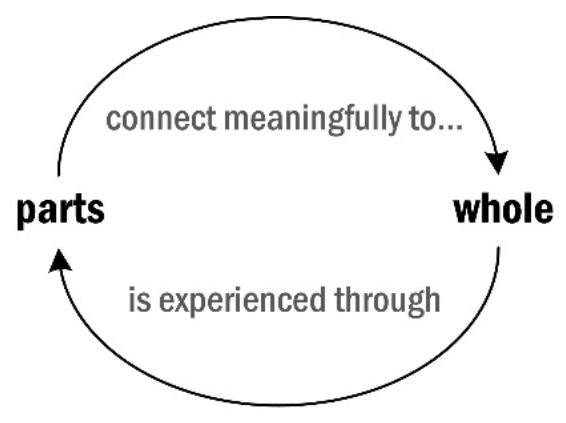

Figure 2: Knowledge and interpretation move from part to whole. In a similar way, they also circle from between past and future (via a position in the present) as well as from individual to humanity as a whole. over the black Singer sewing machine, it looked like magic." The immediate meaning of this 
Friesen

opening line from Angelou, in other words, is given through its connection to the larger quoted passage. A similar dynamism between part and whole is also evident within the phrase itself. Its opening words, "hanging softly," only becomes meaningful when we recognize that it's happening over a sewing machine - the one we surmise belongs to Maya's "Momma." This continues as we read the second part of the sentence, which completes the first: "...it looked like magic." Together, each part becomes more than what it is on its own. And as Dilthey says, words and sentences represent

the simplest case in which meaning arises. In understanding [a given] sentence, each individual word has a meaning, and we derive the sense of the sentence by combining them. We proceed so that the intelligibility of the sentence comes from the meaning of individual words. (pp. 254-255)

This dynamic of part and whole, of pre-understanding and new understanding is relevant not only in understanding a sentence or in summing up an entire life. It also applies to our understanding of an individual child's words and actions, or our "sense" of an entire classroom of children: An enthusiastic word, a concentrated silence or a restless outburst, whether on the part of an individual or a whole class, are things we make sense of via reference to a greater whole. This greater whole could be represented by how the class usually behaves, what the child usually says and does, or what either the child or the class have just experienced-whether it's a fire alarm or an hour in the gym. At the same time, we know that any insight on this basis is partial; it is open to correction as new things come to light about the child, or about the class overall.

\section{Understanding involves our willing, feeling, and thinking.}

We don't just think as humans. We're also always feeling, desiring, evaluating, helping, etc. As Dilthey likes to say, these feelings and "sensings" are inseparably interwoven with our thinking in experience. For example: We don't just think when we hear some music. We feel it, and hopefully we enjoy it. When our appetite is tweaked by something that we might see in an ad, by a memory of a taste or flavor, we don't just "think" abstractly about eating, we desire it. And we might even take a moment to evaluate what we want to eat against what's available or against what we perhaps should eat. Dilthey again describes this sequence abstractly:

Representations, judgments, feelings, desires, acts of will are always interwoven in the psychic nexus: this is [a]...given of psychic life. A harmonious combination of sounds evokes a feeling of pleasure; then a visual perception crowds in upon this calm aesthetic enjoyment and reproduces memories that give rise to a desire; this [may] in turn [be] suppressed on the basis of a judgment [for] fear of the consequences of satisfying the desire. Thus... [our] life display[s] the interweaving of processes belonging to all classes of psychic attitudes. (p. 45) 
Through all moments of experience of these kinds, through all of these "psychic attitudes," we are still engaging in the circular process of understanding, moving from past experiences through present desires to future consequences, from a smaller part to a larger whole. Something similar happens, of course, in reading and learning about Maya's life. This is why Dilthey is not so much interested in thoughts, concepts and ideas in isolation, but rather in the context of our "lived experience," which combines thoughts and ideas with feelings, judgments, and desire. In fact, Dilthey_now speaking specifically about working with children educationally_ goes so far as to say: "We understand a person only to the extent that we feel with him, to which his impulses live within us. We understand only though love" (1960, p. 201). This ultimately applies to the process of interpretation and hermeneutics as much as it does to Dilthey's pedagogics - as I will illustrate below.

\section{The Human Sciences}

The understanding that is exemplified in and through Angelou's biography, as we said, is human science. But what is this human science actually concerned with? Are there many human sciences, or just one? What does it (or what do they) study, how exactly do they relate to the natural sciences, and what is the role of pedagogy in this context? Human science has human life, thoughts, feelings and actions as its focus. And for Dilthey, this also extends to human creations. These creations include not only a book like Angelou's - as well as her many other writings and actions - but also works of drama and philosophy, as well as any other human product: from cathedrals, airports, roadways and memorials, to films and webpages. As Dilthey makes clear, the variety of these creations include any ways that individuals, societies or civilizations leave their mark:

Such understanding ranges from the comprehension of the babblings of children to Hamlet or the Critique of Pure Reason. From stones and marble, musical notes, gestures, words and letters, from actions, economic decrees and constitutions, the same human spirit addresses us and demands interpretation. (1972, p. 323; emphasis in the original)

Whether it is an ancient memorial, a classroom arrangement, or a word from a student, all human creations present us with a common spirit — one that we simultaneously recognize as both our own and as different, as arising from circumstances similar but also different from our own. We immediately understand it at least in part and are drawn to interpret more fully. In looking at the strangely delicate ancient Egyptian bust of Nefertiti or hearing a child's first words, we recognize something of ourselves, we hear at least a faint echo of our own strivings, our own sense of what is desirable and even beautiful.

When it comes to the natural sciences — what we normally just call "science" — we should first recall that, as Dilthey said, we "understand mental life," but "we explain nature." We cannot know something in the natural world - a plant, a mountain range, the weather, or the particles of atomic physics - in terms of our own experiences, thoughts, and feelings. That's because they 
Friesen

come from outside of us as humans; they weren't thought, felt, attempted, or planned earlier by someone else with their own purposes, thoughts, and designs. They have to do with indifferent laws and rules of causality and probability that can be applied to explain one instance or event just as well as another (Figure 3). On the other hand, things that are thought, felt, desired, or planned are always connected to others. And it is from this that they gain their sense or meaning. In the natural sciences, however, things tend to be individuated and atomized, and are given an explanation that is considered final and exhaustive. At least it will not be revised in the light of meaning arising from a future experience, feeling, or action; nor will further reflection or introspection, on its own, provide further insight. In the human world, as one Dilthey commentator puts it, "individual manifestations do not allow themselves to be explained from the outside like physical processes, but to be understood from within - from a live spirit as the expression of an inner comprehension, which also understands and enlivens" (Reble, as quoted in Danner, 2006, pp. 22-23). Dilthey regarded this "understanding from within" as exemplified in disciplines like philosophy, history, law, theology, cultural and literary studies - and also certain approaches to pedagogy, psychology, and sociology (Figure 4). Together, he saw these disciplines as "human sciences;" and working with his students, he led the development of an approach to pedagogy known specifically as "human science pedagogy."

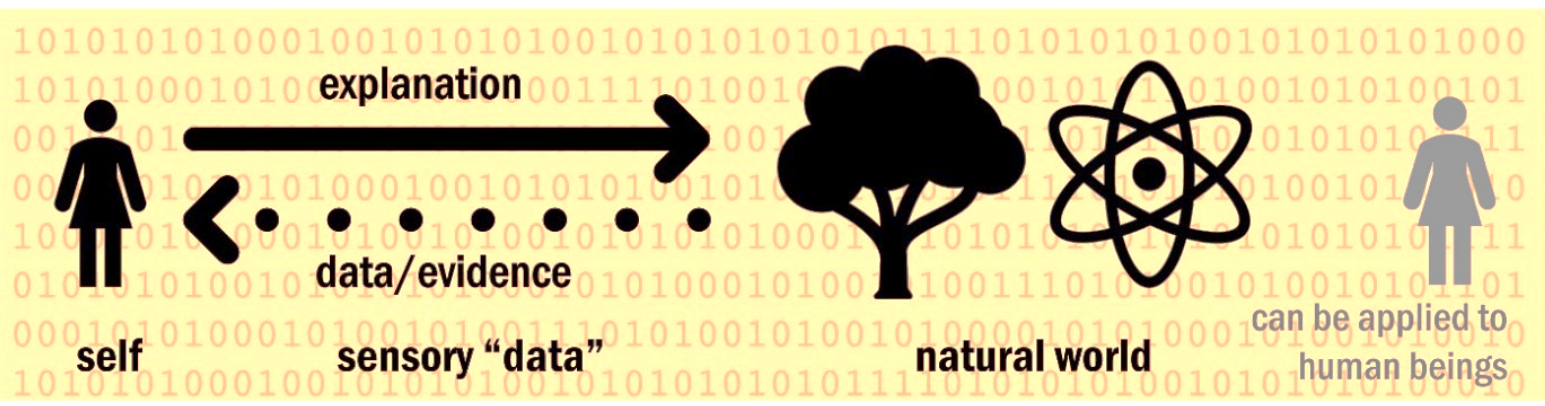

Figure 3: In the natural sciences, we are seen as acquiring sensory data like the zeros and ones of a digital computer. This then allows us to explain, in causal terms, the natural world - as well as some aspects of others' behavior.

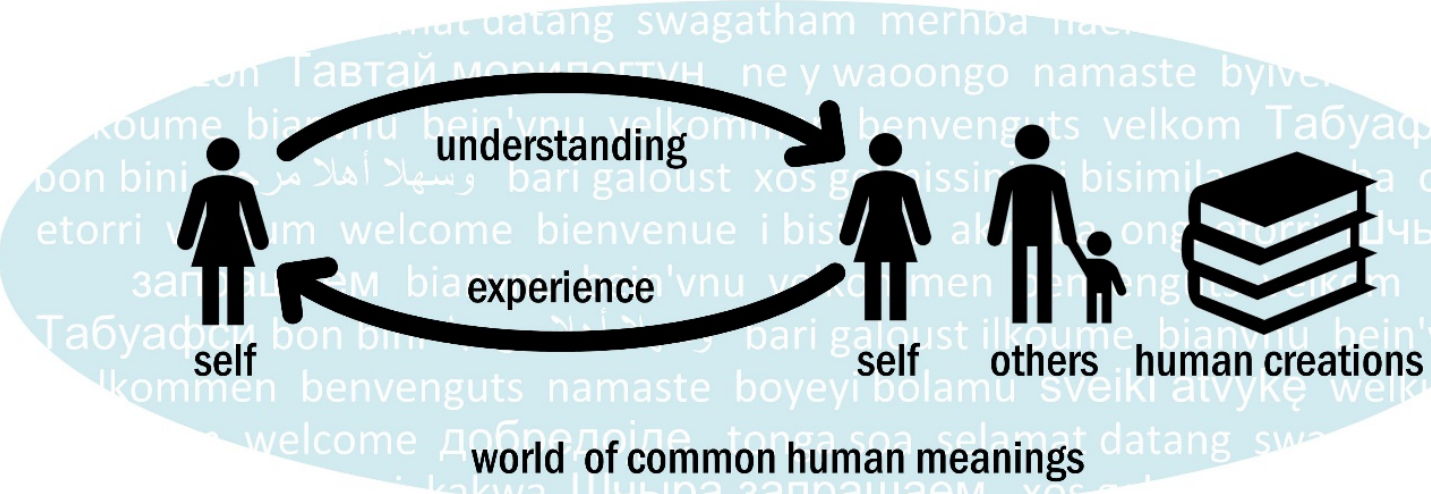

Figure 4: In the human sciences, we are seen as experiencing and understanding ourselves, others, and human creations more broadly within the context of a world of lived and common meanings. 


\section{Human Science Pedagogy}

The difference between human understanding versus natural scientific explanation, finally, lies at the core of Dilthey's conception of pedagogy as a human science. Danner clarifies this artfully in his book Methods of Human Science Pedagogy:

A student's lack of focus is explained through his lack of motivation, by what is happening at home, or even in terms of ill health.... It makes sense to speak of explanation as occurring not only in the realm of nature-since we also link one thing back [causally] to another in the human realm. But in these cases, we don't speak of causal origins; instead we speak of reasons - of grounds that contain a moment of freedom. (2006, p. 40)

In other words: In education — as in other disciplines - it is possible to take the approach of the natural sciences and explain a human phenomenon, for example, why a child acts as he or she does. To do this would be to arrive at decisions, determinations, or diagnoses, deciding or determining that this child has the flu, or arriving at a diagnosis such as attention deficit or oppositional defiant disorder. In keeping with natural scientific explanation, these labels are not so much understood as revisable interpretations but are to be seen as final and exhaustive conclusions produced by explanation - especially when they have been confirmed by an expert. But we know that such labels and explanations can sometimes produce self-fulfilling prophecies and that they can easily harm the child as much as help them. That's why in education, like in any other human context, Danner emphasizes, we are inclined to speak of reasons rather than causes. The difference, as Danner indicates, is that speaking of reasons leaves a space for revision and correction, for the teacher or child to change their mind, their behavior, or their understanding. It allows us, in other words, to exercise freedom - even if in a modest or limited way.

It is in these senses that Dilthey sees pedagogy as a human science - as a "humanities" subject rather than a "science." He thought pedagogy belonged with disciplines like philosophy and theology, and with studies of literature and art - those areas of study that work to interpret and understand rather than to explain. And it is also in this sense that he would today clearly differentiate "pedagogy" from versions of psychology and sociology that seek to label and give final explanations. ${ }^{4}$ As a human science, Dilthey sees pedagogy as above all developing from within - just as understanding itself develops. For example, he defined education as "the methodical activity through which adults seek to form and strengthen the inner life of those growing up." Here, he is speaking of "inner life" in the sense I've been speaking of it in this

\footnotetext{
${ }^{4}$ This is why, in some English texts, Dilthey's understanding of pedagogy is referred to as "humanities pedagogy" and his human sciences simply as the "humanities" (e.g. Troehler, 2003).

5 "Unter Erziehung verstehen wir die planmäßige Tätigkeit, durch welche die Erwachsenen das Seelenleben von Heranwachsenden bilden." The term Dilthey is using here re: inner is "Seelenleben," translated as "psychic life." "Form" and "strengthen" in the original, notably, is "bilden" (1960, p. 190).
} 
Friesen

article: in the sense of experience, in the sense the expression of an inner comprehension which both understands and enlivens. This refers also to a growing capacity for purposes, thoughts, and designs that we also find in the world around us - whether expressed in great works of art or in everyday ideas, feelings, and intuitions.

Arguing against education as delivery of facts or stimuli, Dilthey wrote: "All education is not the result of impressions on the mind, but instead an unfolding from inwards without. Educating means to develop the interrelated strengths of the person" (Dilthey, as quoted in Uhle, 2003 , p. 34). But in speaking of at once forming and strengthening this inner life, Dilthey isn't simply talking about shaping it from the outside, according to norms and expectations that preexist in the adult world, dictating what would be "best" or "most desirable." Instead, he is referring to the act of encouraging the unfolding of something that already has its own form and shape - in terms of the budding nature or the potential adult that already inheres in the child, and that gives the child life and purpose. Again emphasizing the differences separating pedagogy as a human science from the explanations of the natural sciences, Dilthey clarifies:

every person cannot be compared with another; they cannot be derived from the context of the natural world. They carry their purpose based on the inner laws of their development within themselves. [...] This is where a deep need and right of education arises. The living relation between parents and children is not to be gauged through abstract concepts and predates any legal ordering [of the family]. It contains... the duty to develop the child as a person who carries their own purpose within themselves. (Dilthey, as quoted in Uhle, 2003, pp. 48-49)

To educate, for Dilthey, is to foster and encourage the unfolding of what is already inside the person, of who that person is and will become. It is, in other words, to help the child lay out and realize his or her unique life course or purpose. It is to help them lay down their own "biographical path" — of the kind that is celebrated in famous autobiographies like Angelou's or in Dilthey's own unfinished biography of Schleiermacher. Enabling this requires the kind of "feeling with," "experiencing with," and "love" that Dilthey spoke of earlier as lying at the heart of understanding. Here is the full context for Dilthey's powerful words:

We understand a person only to the extent that we feel with him, to which his impulses live within us. We understand only though love. And it is precisely an undeveloped life which we must approach through the art of love, through a dilution of our own feelings in the dark, undeveloped, childish but uncontaminated [feelings of the child]. All reasoning applies only as something secondary. (1960, p. 201)

Dilthey here is again speaking of the "willing, feeling and thinking" that lies at the heart of all efforts at hermeneutics or understanding. The act of loving engagement with a child or young person, Dilthey is saying, also involves the tentative cycling between part and whole (individual 
act and the whole person), and also a similar movement across time: between who this young person is now, and who they will (or might) become, what they have done in the past, and what they are capable of in the present, and what their potential is in the future. Human science pedagogy, in other words, is a hermeneutic science for Dilthey. It is a pedagogy positioned between the movement and also the tensions between part and whole, present and future (and sacrificing one for the other), of individual and humanity or society, and of preunderstanding and new understanding. It is a pedagogy, moreover, directed not to the learning and competencies of the child, but their life course, their biography_ "the highest and most instructive form of the understanding of life" (Dilthey, 2002, p. 221).

\section{References}

Angelou, M. (1969). I know why the caged bird sings. Random House.

Danner, H. (2006). Methoden geisteswissenschaftlicher Pädagogik: Einführung in Hermeneutik, Phänomenologie und Dialektik. Reinhardt.

Dilthey, W. (1960). Pädagogik: Geschichte und Grundlinien des Systems. Vandenhoeck \& Ruprecht.

Dilthey, W. (1972). The rise of hermeneutics. New Literary History, 3(2), 229-244.

Gadamer, H.-G. (2004). Truth and method. Continuum.

Makkreel, R. A. (1977). Introduction. In Dilthey, W. Descriptive psychology and historical understanding (pp. 3-20). Martinus Nijhoff.

Son, S.-N. (1997). Wilhelm Dilthey und die pädagogische Biographieforschung. Springer.

Tröhler, D. (2003). The discourse of german geisteswissenschaftliche Pädagogik - A contextual reconstruction. Paedagogica Historica, 39(6), 759-778.

Uhle, R. (2003). Wilhelm Dilthey: Ein pädagogisches Porträt. Beltz. 